Marek M. Dziekan*

\title{
Na ziemi wroga. Europejskie relacje z wojny hiszpańsko-marokańskiej $1859-1860^{* *}$
}

DOI: http://dx.doi.org/1 0.12775/LC.2019.004

\begin{abstract}
Streszczenie: Podróże kształcą, pozwalają poznać „innego” - zarówno obojętnego „Innego”, jak i przyjaciela czy wroga. Bardzo specyficznym przykładem podróży, które pozwalają poznać „Innego” jako wroga są wyprawy wojenne. Jedna z wojen, toczonych przez Europejczyków na kontynencie afrykańskim w XIX wieku będzie przedmiotem niniejszego opracowania. To wojna hiszpańsko-marokańska z lat 1859-1860, zwana także „wojną afrykańską” lub „wojną tetuańską”. Jest ona bodaj najlepiej opisanym w europejskich źródłach wydarzeniem z dziejów Maroka. Wojna tetuańska znalazła swoje szerokie odzwierciedlenie w kilku relacjach, z których w artykule wezmę pod uwagę trzy, pochodzące z rozmaitych krajów: hiszpańską: Pedro Antonio de Alarcón, Diario de un testigo de la guerra de África, Madrid 1859; brytyjską: Frederic Hardman, The Spanish Campaign in Morocco, Edinburgh and London 1860 i niemiecką: Eduard Schlagintweit, Der spanisch-marokkanische Krieg in den Jahren 1859 und 1860, Leipzig 1863. Wśród autorów mamy wojskowego uczestniczącego w wojnie (Schlagintweit), jak pisarzy, którzy znaleźli się w Maroku jako korespondenci wojenni (Hardman i de Alarcón). Wojna ta była pierwszym konfliktem, który został obszernie udokumentowany zarówno na piśmie, jak i graficznie oraz fotograficznie przez korespondentów, znalazł także swoje odzwierciedlenie w malarstwie.
\end{abstract}

Słowa kluczowe: Maroko, wojna hiszpańsko-marokańska, polityka, Pedro A. de Alarcón, Frederich Hardman, Eduard Schlagintweit

* Prof. dr hab. nauk humanistycznych w zakresie literaturoznawstwa, kierownik Katedry Bliskiego Wschodu i Północnej Afryki na Wydziale Studiów Międzynarodowych i Politologicznych Uniwersytetu Łódzkiego. E-mail: mmdziekan@interia.pl.

** Artykuł napisany przy wsparciu Narodowego Centrum Nauki, projekt nr 2014/15/B/HS3/02260. 


\title{
On the Enemy's Land. European Relations from the Hispano-Moroccan War 1859-1860
}

\begin{abstract}
Journeys let to meet the "Other" - as indifferent as friend or enemy. Quite specific sort of journeys which let to meet and to recognize the "Other" as an enemy are war expeditions. One of such wars, conducted by Europeans in Africa in $19^{\text {th }}$ century is the topic of this article. It is a SpanishMoroccan war 1859-1860, known also as "African war" or "Tetuan war". It is probably the best described event in Moroccan history in European sources. The "Tetuan war" was depicted in some relations. In this study I take into consideration three of them, coming from different countries: Spanish Diario de un testigo de la guerra de África, Madrid 1859 by Pedro Antonio de Alarcón; British The Spanish Campaign in Morocco, Edinburgh and London 1860 by Frederic Hardman; and German Der spanisch-marokkanische Krieg in den Jahren 1859 und 1860, Leipzig 1863 by Eduard Schlagintweit. Among authors we have to do as with a soldier taking part in the war (Schlagintweit) as well with writers who found himself in Morocco as war correspondents (Hardman and de Alarcón). This war was the first in the history so extensively documented as in written sources as in graphic works, photography and painting.
\end{abstract}

Keywords: Morocco, Spanish-Moroccan war, politics, Pedro A. de Alarcón, Frederick Hardman, Eduard Schlagintweit

elem artykułu jest próba odpowiedzi na pytanie, na ile europejskie relacje z hiszpańskiej wyprawy wojennej do Maroka na przełomie 1859 i 1860 roku pozwalają na poznanie wroga i jego kraju. Traktuję więc tu samą wyprawę wojenną jako specyficzny rodzaj podróży zagranicznej. O wskazanym zjawisku rzadko pisało się dotąd w taki sposób, pozostawiając ten typ wyjazdów zagranicznych poza ramami podróżowania, jak gdyby nie mogły mieć one żadnych poznawczych aspektów, jak gdyby poznanie obcego i jego świata z natury rzeczy leżało poza kontekstem takich wypraw. Często zresztą tak było: wróg pozostawał tylko wrogiem, a jego kraj wyłącznie terenem do splądrowania i zdobycia. W rzeczywistości problem wymaga, jak sadzę, szerszych badań teoretycznych i źródłowych. W ostatnich latach takowe są podejmowane, ale szczególnie w kontekście wydarzeń XX-wiecznych, w dodatku znane mi opracowania koncentrują się przede wszystkim na kontekstach wewnątrzeuropejskich. Charlotte Heymel pisze o niemieckich przekazach z I wojny światowej, w których Niemcy relacjonują swoje wrażenia z rozmaitych frontów tego konfliktu (Heymel 2007). Od strony rozważań teoretycznych szczególnie cenny jest tu podrozdział Krieg als Reise? Autorka zwraca uwagę na istotne przekształcenia i przewartościowania w tym zakresie współczesne biura podróży oferują zwykłym ludziom turystyczne wyjazdy do krajów objętych działaniami wojennymi. Ale w aspekcie, któremu poświęciłem moje opracowanie, kontekst jest zupełnie inny. To samo, co w przypadku monografii Heymel, można odnieść do dość dobrze opracowanej problematyki turystyki przybierającej formę pielgrzymki po miejscach wielkich bitew (Ryan 2007). Bliskie mojemu ujęcie tematu prezentuje praca ma- 
gisterska Kerstin Wölki obroniona na uniwersytecie we Fryburgu Bryzgowijskim, tam jednak baza źródłowa została całkiem inaczej ukształtowana (Wölki 2007).

Praca zbiorowa pod redakcją Barbary Korte i Horsta Tonna dotyczy z kolei korespondentów wojennych i ich roli w kontekście historycznym, poczynając od XIX wieku (Korte, Tonn 2007). W tym opracowaniu pojawiają się także teksty dotyczące wojen prowadzonych na innych kontynentach. Problematyka roli korespondentów podczas działań zbrojnych staje się obecnie istotnym przedmiotem badań (Knightley 2004 - wyd. 1 z 1975 roku kończyło się na wojnie wietnamskiej; Allan, Zeliger 2004). Ich przekrój, a w pewnym zakresie także dzieje ukazuje właśnie wspomniana książka.

W tym studium, mającym na celu ukazanie Maroka poprzez zachodnie relacje z wojny hiszpańsko-marokańskiej z lat 1859-1860, spróbuję ukazać specyfikę spojrzenia na obcy świat tych ludzi, których celem nie było poznanie tamtej rzeczywistości, innej kultury, „innego”, lecz jego pokonanie i podporządkowanie - a zatem „inny” to przede wszystkim „wróg”, co może, choć - jak się okaże - nie musi, wpływać na jego recepcję i obraz. Pod uwagę zostaną wzięte wybrane trzy relacje, których autorami są przedstawiciele różnych europejskich nacji, występujący w dwóch różnych rolach: Hiszpan Pedro Antonio de Alarcón i Brytyjczyk Frederic Hardman, których można określić jako korespondentów wojennych oraz żołnierz - Niemiec Eduard Schlagintweit. Nie są to oczywiście wszystkie europejskie książkowe opisy tej wojny, a podstawą wyboru stał się fakt bezpośredniego w niej uczestnictwa wzmiankowanych autorów.

\section{Kontekst historyczny relacji}

Wojnę hiszpańsko-marokańską zwie się także „wojną afrykańską” i „wojną tetuańską” - to drugie określenie jest typowe dla autorów hiszpańskich, ostatnie zaś dla arabskich (ḥarb Tițān). Panuje opinia, że to właśnie ta wojna, a nie przegrana wojsk marokańskich nad İslī w 1844 roku stanowiła swego rodzaju punkt zwrotny w polityce wewnętrznej i zagranicznej maȟzanu (rządu marokańskiego). Biorąc pod uwagę przyczyny wojny, historycy hiszpańscy określają ją wprost jako „trudną do wytłumaczenia” (Tunón de Lara et al. 2012: 459). Chodziło w gruncie rzeczy o mało znaczący konflikt graniczny w Ceucie, który tak jest opisywany przez marokańskiego historyka z epoki, Aḥmad an-Nāṣirī:

Przyczyna rozpadu układu pokojowego z Hiszpanami była następująca. Było zwyczajem chrześcijańskich mieszkańców Ceuty i muzułmańskiego plemienia Anğara, że ustawiali swoje posterunki na obszarze granicznym między nimi. Chrześcijanie budowali baraki z desek, zaś muzułmanie szopy kryte trzciną lub podobnymi materiałami. Pod koniec panowania sułtana Mawlāy 'Abd ar-Raḥmāna, niech Bóg będzie mu miłościw, chrześcijanie z Ceuty zbudowali na pograniczu domek z kamienia i gliny, zawieszając na nim flagę swojego władcy nazywaną przez nich „Corona”. Anğarowie zwrócili się do nich, że powinni zburzyć tę budowlę, niezgodną z dotychczasowym zwyczajem i tak jak dawniej zostawić drewniane baraki. Kiedy chrześcijanie odmówili, Anğarowie zaatakowali ten domek, zburzyli go, zerwali „Coronę” i zanieczyścili ją kałem. Zabili przy tym kilku ludzi i zaczęli atakować Ceutę, docierając aż do murów. Mieszkańcy Ceuty poskarżyli swojemu przedstawicielowi w Tangerze, który zwrócił się ze skargą do tamtejszego przedstawiciela sułtana, którym był wtedy Abū `Abd Allāh Muhammad 


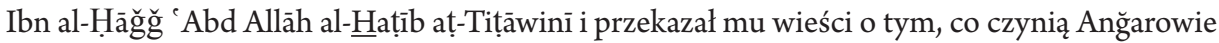
wobec ceutańczyków. Al-Hुațīb odrzucił jego zarzuty, ten jednak zażądał wezwania dwunastu Anğarów, których wymienił po imieniu, do Tangeru ${ }^{1}$ i stwierdzil, że muszą zostać zabici za karę za ich czyny. Al- $\underline{H}$ ațīb uznał to żądanie za wygórowane, ale prawdopodobnie rozmawiał na ten temat $\mathrm{z}$ angielskim ambasadorem ${ }^{2}$. Ten zaś rzekł mu:

- Przyprowadź oskarżonych, których oni żądają, a kiedy przybędą i okaże się, że Hiszpanie mają rację, to gwarantuję ci, że nic się im nie stanie.

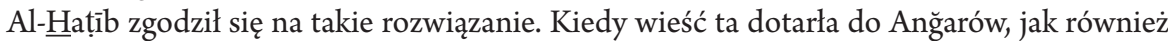
i to, że napisze on do sultana w sprawie tej dwunastki, udali się do Aš-Šarīfa Sīdī al-Ḥāğğa 'Abd as-Salāma Ibn al-'Arabīego al-Wazzānīego ${ }^{3}$ i powiedzieli mu, że Al-Hațīb nie jest przywiązany ani do sułtana, ani do muzułmanów. „Robi to, co każą mu chrześcijanie, i to tylko wzmacnia ich śmiałość przeciwko nam. Przyszliśmy do ciebie, żebyś powiadomił sułtana o naszej sprawie i poprosił go, żeby wsparł nas plemionami mieszkającymi po sąsiedzku, to poradzimy sobie z tą sprawą".

W tym czasie zmarł sultan Mawlāy `Abd ar-Raḥmān, niech Bóg będzie mu miłościw, a na tron wstąpił jego syn Sīdī Muhammad, który przybył do Miknāsy i poparli go wszyscy mieszkańcy Maroka.

Aš-Šarīf Sīdī al-Ḥăğğ ’Abd as-Salām napisał do niego na prośbę ludzi z plemienia Anğara i opisał mu ich sytuację. Sułtan poradził się w tej sprawie ludzi ze swojego otoczenia, którzy poradzili mu wojnę. Sułtan skłonił się do tej decyzji, ponieważ nie mógł sobie pozwolić na zabicie dwunastu muzułmanów na żądanie wroga i wedle jego wyboru wobec przedstawicieli różnych krajów. Stwierdzil, niech Bóg będzie mu miłościw, że nie może spełnić takiego żądania i zdał się na łaskę Boga. Następnie wysłał swojego sługę, Al-Hāăğğa Muhammada Ibn al-Hāăğğa

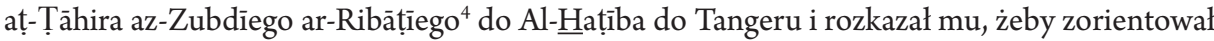
się w sprawie, zbadał sytuację i nie godził się na pokój jak tylko wtedy, kiedy okaże się, że nie ma innego wyjścia.

Ludzie wokół sułtana zaczęli mu dawać dobre rady i pomniejszali w jego oczach siłę wroga, choć nie jest dobrym zwyczajem pomniejszanie wroga i poniżanie go, nawet jeśli jest słaby i podły. Kiedy Az-Zubdī przyjechał do Tangeru, spotkał się z Al-Hațîbem i wypytał go o wszystko. Okazało się, że Al-프atịb skłania się ku pokojowi i odmówił mu pomocy w tym względzie, przedstawiając mu pismo od sułtana, w którym to jemu zostały przekazane pełnomocnictwa w zakresie przedmiotowej sprawy. W tej sytuacji Al-Hatịib wycofał się i przestał się wypowiadać na ten temat. Ostatecznie Az-Zubdī zerwał rozmowy z przedstawicielem Hiszpanii, nastąpiła decyzja o wojnie, a on poszedł swoją drogą (An-Nāṣirī 2010: 330-331)

Podobnie przyczyny wojny są opisywane we wszystkich opracowaniach, tak arabskich, jak zachodnich, dotyczących tego konfliktu. W efekcie opisanych wydarzeń 22 października Hiszpania wypowiedziała Maroku wojnę, której skutkiem było zajęcie 4 lutego 1860 roku Tetuanu i podpisanie 25 marca tegoż roku układu pokojowego. Wojna ta miała jednak, jak się wydaje, większe znaczenie dla polityki wewnętrznej Hiszpanii owych czasów niż dla polityki zagranicznej tego kraju. Dużo ważniejszy pozostawał jej wymiar propagandowy niż praktyczny. Została ona „entuzjastycznie przyjęta przez społeczeństwo i rozbudziła hiszpański nacjonalizm, bardziej skłonny do rozpamiętywania przebrzmiałej chwały niż

\footnotetext{
1 W rzeczywistości chodziło o Ceutę.

2 Brytyjskim przedstawicielem w Maroku był wtedy John Drummond Hay.

3 Jedna z ważniejszych postaci życia religijnego w Maroku, związany z Tangerem, przywódca zāwiyi bractwa sufickiego wazzāniyya, zm. 1892.

4 Urzędnik mah̆zanu i dyplomata, żył w latach 1805-1886, był ambasadorem Maroka w Wielkiej Brytanii, we Francji, Włoszech i w Belgii.
} 
budowania przyszłości” (Tuñón de Lara et al. 2012: 459). Rozważania nad jej sensem do dziś nurtują hiszpańskich badaczy (Serrallonga Urquidi 1998; Cayal Valero 2012; Velasco 2013).

Jak twierdzi José Ángel Montañés, wojna ta była także pierwszym konfliktem w dziejach, który został obszernie udokumentowany graficznie i fotograficznie przez korespondentów wojennych. Znalazł także swoje odzwierciedlenie w sztuce (Ángel Montañés 2013).

\section{Trzy relacje z wojny i ich autorzy}

\section{Pedro Antonio de Alarcón}

Pochodzący z Kadyksu Pedro Antonio Joaquín Melitón de Alarcón y Ariza (1833-1891) (Chandler, Schwartz 1991: 133-134; Gies 2008: 413-416; Baczyńska 2014: 323-325) wywodził się ze zubożałej szlacheckiej rodziny andaluzyjskiej. Należy do najwybitniejszych postaci XIX-wiecznej literatury hiszpańskiej i reprezentuje nurt tzw. regionalizmu, charakterystyczny dla konserwatywnych twórców o poglądach ultrakatolickich. Co ciekawe, w młodości de Alarcón był antyklerykałem, lecz w wyniku kolejnych wydarzeń politycznych w Hiszpanii znalazł się po drugiej stronie barykady. Jest autorem kilku powieści oraz wielu opowiadań i sztuk teatralnych. Za najwybitniejszą powieść de Alarcóna jest uważana El escándalo (1875). Jego utwory były dość popularne w tamtym czasie także w Polsce i wiele z nich zostało przetłumaczonych, a wspomniana powieść nawet dwukrotnie - jako Zgorszenie (1884) i Skandal (1901). Diario de un testigo de la guerra de África (Dziennik świadka wojny afrykańskiej) (de Alarcón 1859,1861$)^{5}$ zajmuje w jego twórczości miejsce specjalne. Nie jest to jedyne jego dzieło związane z podróżami, ale jedyne, które wiąże się z szeroko pojętym Orientem. Diario to owoc pobytu de Alarcóna w Maroku podczas rzeczonej wojny, w której brał udział jako korespondent wojenny czasopisma „El Museo Universal” ukazującego się w latach 1857-1869. Książka cieszyła się wielką popularnością wśród czytelników, o czym świadczy znaczny nakład - 50 tysięcy egzemplarzy. Już w 1861 roku ukazało się jej drugie wydanie ${ }^{6}$. To właśnie ona, jak pisze Jesús Menéndez Pérez (Pérez 2008: 158) przyniosła pisarzowi prawdziwą sławę, a nie publikowane wcześniej teksty beletrystyczne. Alarcón był członkiem Kortezów, a w 1877 roku został członkiem Królewskiej Akademii Hiszpańskie j (Real Academia Española) ${ }^{7}$.

\footnotetext{
${ }^{5}$ W tym opracowaniu odnoszę się do wydania drugiego. Na pierwszym wydaniu widnieje data 1859, choć wojna skończyła się wiosną 1860 roku i relacja jest doprowadzona do samego jej końca.

6 Kolejne wydania: 1863, 1892, 1898, 1923, 1942, 2004, 2005.

7 Warto dodać, że relacja de Alarcóna to oczywiście niejedyna książka o wojnie, jaka ukazała się w tamtych czasach w Hiszpanii, por. np. Balaguer 1860a; R.R. de M. 1860. Ciekawym dokumentem ukazującym jak Hiszpania zareagowała na zwycięstwo, jest niewielka książeczka Reseña de los festejos celebrados en Barcelona en los primeros dias de mayo de 1860 con motivo del regreso de los voluntarios de Cataluña y tropas del ejército de África (Balaguer 1860b), zawierająca m.in. wiersze poświęcone tej wyprawie i żołnierzom hiszpańskim. Interesującym wizualnym dokumentem jest zbiór litografii Episodios de la Guerra de África (Moro, Bouret 1859-1860), a przede wszystkim Atlas histórico y topográfico de la guerra de África sostenida por la nacion española contra el imperio marroqui en 1859 y 1860.
} 
Wśród analizowanych przeze mnie relacji praca de Alarcóna zajmuje pozycję szczególną, jest bowiem jedynym dziełem z uwzględnianych tu przeze mnie, które zostało napisane przez obywatela państwa bezpośrednio zaangażowanego w wojnę. To sprawia, że spojrzenie na Maroko musi być specyficzne: to wróg bezpośredni, którego należy pokonać. Nie może więc de Alarcón w żaden sposób patrzeć na wydarzenia „z zewnątrz” - jest w nie zaangażowany dużo bardziej niż autorzy z innych krajów europejskich, o których będzie mowa później.

Hiszpan zawitał do Ceuty 12 grudnia, a zatem już po rozpoczęciu działań wojennych, wyjechał zaś z Afryki przed ich zakończeniem, stąd relacja z ostatniego okresu wojny została napisana na podstawie przekazów uzyskanych od uczestników walk, już w Madrycie. Książka jest podzielona na 60 opatrzonych tytułami rozdziałów, Prolog (Prólogo), Epilog (Epilógo) i Aneks (Apéndice).

Diario to książka bogato ilustrowana, dowodząca istoty ilustracji dla wzmocnienia przekazu słownego. Tak jest przede wszystkim w przypadku pierwszego wydania, gdzie mamy ponad 100 rysunków i fotografii, z czego około połowa to ilustracje ukazujące Maroko i Marokańczyków. W wydaniu drugim mamy już tylko 20 ilustracji, które w związku z tym robią dużo mniejsze wrażenie na czytelniku i, rzecz jasna, nie unaoczniają tak wyraźnie przekazu słownego. Ilustracje w wydaniu pierwszym ukazują zarówno kraj, jak i ludzi. Czytelnik dowiaduje się, jak wyglądają marokańskie wioski i miasta, jak wyglądają ich zwykli mieszkańcy, ale także przedstawiciele elit, żołnierze, Żydzi, kobiety i dzieci. Mamy ilustracje z życia codziennego i z pola walki. W ten sposób przekaz de Alarcóna zyskuje na wyrazistości. Wróg, „obcy”, „inny” staje się bliższy, lepiej poznany, tym bardziej że w wiele ilustracji towarzyszy opowieściom o tych właśnie miejscach czy ludziach.

Relacja de Alarcóna jest dość szczegółowa i traktuje się ją niejednokrotnie jako poważne źródło historyczne. Takiego znaczenia rzeczywiście pracy tej odmówić nie można. Wydarzenia są opisane chronologicznie i dość dokładnie, jednak de Alarcón nie zarzuca czytelnika zbytnio szczegółami technicznymi albo liczbami określającymi wielkość wojsk w poszczególnych potyczkach. Nie jest to zbeletryzowana wersja wojny, ale z drugiej strony nie ma nic wspólnego z suchą relacją o charakterze choćby popularnonaukowym. Zdecydowanie bliżej jej do relacji reporterskiej, choć i taką w rzeczy samej nie jest. Autor podkreśla, że jego książka nie jest historią wojny, lecz właśnie „diariuszem” (de Alarcón 1861: 48-49). Opisy miejsc i bitew mają bardzo obrazowy charakter, zresztą autor zwraca uwagę na z natury „malarski” wymiar niektórych krajobrazów, odnosząc odzwierciedlane widoki bezpośrednio np. do obrazów Delacroix (ibid.: 236). Ponieważ wojna hiszpańsko-marokańska odbywała się w bardzo trudnych warunkach pogodowych, w dodatku żołnierzy dręczyły rozmaite choroby, do tych wątków de Alarcón niejednokrotnie powraca ${ }^{8}$.

W książce, której poszczególne rozdziały drukowano w czasopiśmie, autor zwraca się bezpośrednio do czytelnika (zazwyczaj „mój przyjacielu”). Praca pełna jest podniosłych wykrzykników i - ogólnie rzecz biorąc - ma dość egzaltowany styl. Wynika to prawdopodobnie z tego, jak ważne psychologicznie znaczenie miała ta wojna dla Hiszpanii. Praca ma dość „orientalistyczny” (w pojęciu XIX-wiecznym, nie saidowskim) charakter, choć Maroko dla de Alarcóna nie było całkiem obce, jako że wywodził się z Andaluzji. Wielokrotnie zresztą

8 Element meteorologiczny jest dość typowy dla opisów wojen - wskazuje na to edytor Diariusza wyprawy wiedeńskiej króla Jana III (Królikowski 2003: 10). 
wskazuje na podobieństwo Maroka i tej części Hiszpanii (de Alarcón 1861: 466). Pisarz głęboko przeżywał swoją wiarę, stąd niejednokrotnie podkreślał wyższość cywilizacji zachodniej (chrześcijańskiej) nad muzułmańską, co jednak wydaje się mieć charakter przede wszystkim retoryczny (ibid.: 169, 182, 473). To nie przeszkadza mu bowiem zachwycać się zarówno osiągnięciami cywilizacji islamu w zakresie kultury materialnej (piękne i szczegółowe opisy architektury - tak sakralnej - np. liczne „marabuty” czy Wielki Meczet w Tetuanie, jak świeckiej - dom bogatego notabla w tymże mieście), jak i godnymi podziwu cechami charakteru muzułmanów oraz wierności tradycji, na co kładzie szczególny nacisk (ibid.: 162-163). Nie jest to oczywiście admiracja bezkrytyczna, choć trudno wytyczyć granicę między spojrzeniem na „wroga” a stereotypami na temat państwa marokańskiego, jak np. na s. 282-283, gdzie mowa o muzułmańskim despotyzmie i ograniczonych prawach kobiet $\mathrm{w}$ islamie.

Cała książka ukazuje ambiwalentny stosunek de Alarcóna do Maroka, Marokańczyków i cywilizacji arabsko-muzułmańskiej. Autor określa sam siebie jako „admirador y enemigo de los moros" (ibid.: 401). Zgodnie z konwencją opisu wojny bardzo często pisze o Marokańczykach czy też „Maurach” po prostu „wróg”, ale nie widać jednoznacznie wrogiego nastawienia do przeciwnika. De Alarcón nie opisuje wojny jako jakiejś romantycznej wyprawy, włączając do książki czasem krwawe i okrutne obrazy starć oraz wspominając o ofiarach bitew zarówno po jednej, jak i po drugiej stronie. Mogą zaskakiwać dość liczne opisy ciał zabitych Marokańczyków - i Arabów, i Berberów czy żołnierzy czarnoskórych. Autor podkreśla szlachetność ich rysów i doskonałą budowę ciała (ibid.: 99, 104, 223).

Jak na relację z wojny przystało, Alarcón opisuje także armię marokańską jako taką i jej taktykę wojenną, uznając tę ostatnią (i słusznie) za nieprzystającą do ówczesnej rzeczywistości. Taktyka typowa dla marokańskiej armii polegała na bardzo szybkim ataku, a właściwie jego symulacji, oddaniu strzału jednocześnie przez cały oddział i bardzo szybkim odwrocie, co początkowo może robić duże wrażenie na przeciwniku. Kawalerię marokańską określa mimo to jako „bajeczną”, zachwyca się końmi i jeźdźcami, „synami natury” (ibid.: 253).

Bardzo ważne dla obrazu Marokańczyków opisy znajdujemy w części pracy poświęconej Tetuanowi po zdobyciu miasta przez Hiszpanów (Tițaān fī kitāb „Yawmiyyāt šāhid 'an hạarb Ifrikijjā” 2017) ${ }^{9}$. De Alarcón spaceruje po mieście w towarzystwie swojego przyjaciela i tłumacza ${ }^{10}$, docierając do różnych zakątków i zaułków miasta, niedostępnych innym Hiszpanom. Marokańczycy jednak (poza Żydami) nie zwracają na nich uwagi, jak gdyby nie przyjmując do wiadomości własnej klęski - traktują zdobywców „niczym powietrze”, pozostają panami w swoim mieście przez odcięcie się od rzeczywistości przegranej. Tylko Żydzi zachowywali się inaczej, witając z radością zdobywców. Te reakcje de Alarcón opisuje z wyraźnym niesmakiem, co być może jest efektem jego antysemityzmu, na co zwraca uwagę Pérez (de Alarcón 1861: 455; Pérez 2008: 164).

Obraz Maroka i Marokańczyków w dziele de Alarcóna jest wielowymiarowy. Sposób narracji sprawia, że podczas lektury nie koncentrujemy się na samych wydarzeniach wojennych, lecz możemy dowiedzieć się sporo zarówno o kraju, jak i jego mieszkańcach. „Wróg”

9 Tekst jest skoncentrowany prawie wyłącznie na opisie Tetuanu, ale zawiera wiele interesujących uwag o charakterze ogólnym.

10 Byli to Marokańczyk, Mușțafā 'Abd ar-Rahmmān i Anibal Rinaldy, tłumacz generała O’Donella, por. de Alarcón 1861: 27. 
nie został ukazany jako ktoś jednoznacznie zły i godzien pogardy. Hiszpan stara się spojrzeć na kraj i jego mieszkańców obiektywnie, czasem przez okulary orientalizmu, tak modnego w XIX wieku w piśmiennictwie i sztuce Europy. Zresztą wojna tetuańska przyczyniła się do rozwoju malarstwa „orientalistycznego” w Hiszpanii, a samej wojnie niezwykle piękne obrazy poświęcił Mariano Fortuny (Crespo Giménez 2017). Znane są także np. talerze z obrazkami o tej tematyce.

De Alarcón jako Andaluzyjczyk podchodzi do Maroka w sposób szczególny. Choć jest chrześcijaninem, wydaje się, że czuje swego rodzaju pokrewieństwo z tamtejszą kulturą. W tym kontekście trudno zgodzić się z opinią Péreza, że de Alarcón nie rozumie tej obcej cywilizacji i patrzy na nią wylącznie przez pryzmat orientalizmu (przez tego autora rozumianego wyraźnie po saidowsku). Moim zdaniem chodzi tu raczej o pewien dystans poznawczy skierowany do czytelnika, dla którego cywilizacja islamu jest rzeczywiście obca. Jeśli de Alarcón zdaje się dziwić niektórym zwyczajom i obyczajom marokańskim, to chodzi o sposób retorycznego zbliżenia się do odbiorcy, który rzeczywiście będzie się temu wszystkiemu dziwił.

Diario de un testigo Pedro de Alarcóna to niezwykle interesujący przykład relacji z wojny, która jest jednocześnie w pewnym zakresie relacją z podróży - zarówno w przestrzeni, jak i podróży mentalnej. Ziemia wroga nie charakteryzuje się wyłącznie wrogością. Wróg choć z założenia jako wróg musi wzbudzać przerażenie - nie został odczłowieczony. Książka miała na celu podniesienie na duchu Hiszpanów i z pewnością do tego się przyczyniła, ale nie przez pomniejszanie i upodlanie wroga, co wydaje się w pełni logiczne. Bo jakże można czuć całkowitą dumę ze zwycięstwa nad wrogiem, który jest słaby, biedny i podły?

\section{Frederick Hardman}

Frederick Hardman (1814-1874) („Contemporary Literature. III. Magazine-Writers” 1879: 235-236; A[lger] 1890: 347) był brytyjskim dziennikarzem i pisarzem. Wywodził się ze statecznej, kupieckiej rodziny, ale niespokojny duch nie pozwolił mu na kontynuowanie rodzinnej tradycji i w 1834 roku dołączył do Legionu Brytyjskiego w Hiszpanii, biorąc udział w tzw. I wojnie karlistowskiej (1833-1840) (Tuñón de Lara et al. 2012: 411 i nast.), w czasie której został ranny. Na tym zakończył jednak swoją aktywność jako żołnierz, poświęcając się odtąd pisarstwu i dziennikarstwu. Najsłynniejszą jego powieścią jest The Student of Salamanca (1847), będąca rodzajem reminiscencji z pobytu w Hiszpanii w czasie wspomnianej wojny. Również Półwyspowi Iberyjskiemu poświęcił Peninsular scenes and sketches (1846). W sumie był autorem, tłumaczem ( $\mathrm{z}$ niemieckiego, francuskiego i hiszpańskiego) lub redaktorem kilkunastu książek. Od 1850 roku był też zagranicznym korespondentem „The Times”, niejednokrotnie działając w praktyce jako reporter wojenny - w czasie wojny krymskiej (1853-1856), francusko-pruskiej (1870-1871) i oczywiście w trakcie wojny hiszpańsko-marokańskiej, której poświęcił pracę The Spanish Campaign in Morocco (Hardman 1860).

Obszerna relacja z wojny hiszpańsko-marokańskiej została napisana na podstawie korespondencji, jakie wysyłał Hardman z Hiszpanii i Maroka do dziennika „The Times” i tam publikował w okresie od 17 listopada 1859 do 10 kwietnia 1860 roku. Książka rozpoczyna się relacją z Malagi, kończy zaś relacją z Kadyksu. Pisana w formie dość regularnych kore- 
spondencji publikacja zachowuje oryginalny kształt przez bezpośrednie zwroty do czytelników (podobnie jak de Alarcón Hardman stosuje jednak po prostu zwrot „you”) i odnoszeniem się nie do poprzednich rozdziałów, lecz do poprzednich listów/korespondencji. W ten sposób został utrwalony naturalny i aktualny przekaz o wydarzeniach, do jakich doszło w Maroku, ale prawie wyłącznie z perspektywy kwatery głównej wojsk hiszpańskich, gdzie stacjonował Hardman. Korespondencje były pisane kolejno z Malagi, Ceuty, obozów wojskowych między Ceutą i Tetuanem, wreszcie z samego Tetuanu.

Autor nie brał oczywiście bezpośredniego udziału w walkach, pracował bowiem tylko jako korespondent wojenny. Mając na uwadze to, w jaki sposób działają współcześni nam korespondenci, można było spodziewać się żywego przekazu ze zmagań hiszpańsko-marokańskich, a także dużego zainteresowania autora teatrem wydarzeń jako rodzajem nowego doświadczenia poznawczego zarówno dla niego, jak i dla czytelnika. W rzeczywistości tak, niestety, nie jest. Wytłumaczyć to można do pewnego stopnia faktem, że Hardman pisał już relacje z innych odległych od Wielkiej Brytanii krajów, choćby z Krymu, więc swego rodzaju „egzotyka”, w tym muzułmańska, nie była mu obca i zapewne to samo zakładał w przypadku czytelników. Zastanawia jednak, na ile było to ukształtowane przez osobiste zainteresowania dziennikarza, na ile zaś przez znajomość gustów odbiorców „The Timesa”.

Kampania hiszpańska w Maroku była w znacznym stopniu ograniczona warunkami pogodowymi - to prawda, ale dziennikarz wydaje się nieco zbyt zaaferowany pogodą. Jak wspomniałem, pisze o tym także de Alarcón, ale tu niemal każda korespondencja zawiera informacje dotyczące kierunku wiatru, deszczu, burz, temperatury itp. Całą relację przesycają bardzo szczegółowe informace dotyczące przede wszystkim armii hiszpańskiej. Autor dokładnie opisuje jej skład i organizację. Opisuje więc to, czego jest najbliżej, mniej koncentrując się na świecie wokół. Wielokrotnie wskazuje na swoją zewnętrzną wiedzę o Hiszpanii, od tej strony był więc do wyprawy dobrze przygotowany. Opisy, jakie znajdujemy w książce, dotyczą głównie walk z perspektywy hiszpańskiej. Autor dokładnie relacjonuje skład armii i uzbrojenie Hiszpanów, charakteryzuje głównych dowódców i kolejne potyczki, gdzie wylicza szczególowo liczbę zabitych i rannych Hiszpanów, niewiele miejsca poświęcając „wrogowi” - w jakimkolwiek zresztą kontekście. Nawet od strony czysto militarnej znajdujemy u Hardmana tylko kilka miejsc, gdzie na chwilę zatrzymuje się nad wojskowymi zdolnościami (czy raczej nieudolnością) Marokańczyków. Najwyraźniej opiera się tu przede wszystkim na swojej wiedzy ogólnej opartej na XIX-wiecznych stereotypach ( $w$ aspekcie militarnym zresztą niewiele odbiegających od rzeczywistości). Już na początku wspomina o wojowniczym charakterze Arabów, dodaje też uwagi o słynnym, stereotypowym fanatyzmie i pogardzie dla śmierci (Hardman 1860: 1, 40), odmawiając im znajomości nowoczesnej taktyki wojennej (ibid.: 112). W innym miejscu opisuje ową taktykę, podobnie jak hiszpański reporter (ibid.: 96). Wywierała ona, przez swą egzotykę, spore wrażenie na wszystkich Europejczykach odwiedzających Maroko, stanowiła bowiem także rodzaj zabawy czy gry, zwanej dzisiaj fantāziyā. Jednak uzbrojenie Marokańczyków poznawał głównie po tym, w jakim stanie chwytani byli jeńcy i jak wyglądały ciała zabitych na polu walki, których czasem przeciwnicy nawet nie zdążyli pochować. Maurowie są byle jak odziani, w same tylko $h \bar{a}^{\prime} i k i$ (tradycyjny marokański strój), brudni, z przestarzałą bronią. Takie obrazki powtarzają się w relacji kilkakrotnie. Zwraca tu uwagę fakt całkiem innego opisu Maurów przez Hiszpana i Brytyjczyka - autorzy podkreślają odmienne detale. Trudno stwierdzić u Hardmana jakiś dodatkowy cel tych obrazów poza czystym, chłodnym 
opisem. Dziennikarz nie stara się tworzyć spójnego portretu wroga, daleko mu do obrazowości orientalistycznego malarstwa tamtych czasów, które przecież często inspirowało się opowieściami podróżników, a niektórzy malarze nigdy na własne oczy Orientu nie doświadczyli. Książka Hardmana w najmniejszym stopniu nie posłużyłaby im jako natchnienie, choć w jednym miejscu wspomina o „typach”, które z pewnością spodobałyby się takim artystom (Hardman 1860: 81-82).

Być może przyczyną tego jest fakt, że Hardman nie miał zbyt wielu możliwości bezpośredniego kontaktu ani $\mathrm{z}$ „wrogiem”, ani z prawdziwym Marokiem. Jeśli chodzi o miasta, to poza Ceutą, znacznie już zeuropeizowaną, jedynym prawdziwie marokańskim miastem, jakie do pewnego stopnia poznał Brytyjczyk, był zdobyty i mocno zdewastowany przez Hiszpanów i wcześniejsze walki wewnętrzne Tetuan. Do opisu miasta autor kilkakrotnie powraca (ibid.: 226, 237, 242, 256-257, 269, 322). Nie wyraża zachwytu Tetuanem. Podobnie jak wielu innych podróżników europejskich zwraca uwagę na brud, wąskie uliczki i „ślepe” ściany na zewnątrz. Doskonale jednak zdaje sobie sprawę z powodów takiego układu architektonicznego maghrebskiego miasta i nie komentuje go w żaden sposób, jak to czyniło wielu jego zaskoczonych tym widokiem poprzedników, co świadczy o pewnym kulturowym przygotowaniu do wyprawy.

Stosunkowo sporo miejsca, podobnie jak u wielu innych europejskich podróżników, poświęca dzielnicy żydowskiej i sytuacji Żydów w mieście (ibid.: 226-233, 242). Zwraca przy tym uwagę nie tylko na ich domy (w tym przypadku zniszczone i obrabowane po zamieszkach, jakie wybuchły po zdobyciu miasta przez Hiszpanów), ale także na naturę ludzi. Opisuje ich jako skromnych, biednych i uniżonych wobec zdobywców, którzy przecież byli w jakimś sensie ich wyzwolicielami. W przypadku miejscowych Arabów podkreśla natomiast ich dumę czy nawet poczucie wyższości, choć to właśnie oni byli pokonanymi. Rozszerza zresztą to wrażenie na tamtejszych muzułmanów w ogóle i pisze o tym z dużym podziwem (ibid.: 245-246). Zgadza się więc w tym aspekcie ze swoim hiszpańskim kolegą. Warto dodać, że to cecha typowa dla Arabów „od zawsze” po dziś dzień, bez względu na warunki i sytuację.

Ktoś, kto oczekiwałby w relacji Hardmana „orientalistycznych” (w XIX-wiecznym sensie) obrazów afrykańskiej przyrody i jej mieszkańców, będzie bardzo zawiedziony. Kontrastuje to z wielostronną recepcją Maroka u omówionego wyżej de Alarcóna. Śródziemnomorski krajobraz północnych wybrzeży kraju w skromnych w tym zakresie opisach niezbyt autora zaskakuje w porównaniu z południową Hiszpanią (może poza wspomnianymi ulewami). Wydaje się także, że nawet niezbyt go interesuje. Czasem tylko wspomina o żyjących tam zwierzętach, przede wszystkim o królikach - w kontekście możliwości polowania na nie... (ibid.: 127-128, 267).

Relacja Brytyjczyka ma dość specyficzny charakter, stając się w większym stopniu zapisem działań wojennych niż opisem wyprawy z jej wszelkimi aspektami - tak militarnymi, jak innego typu. Wróg, czyli muzułmanin, Marokańczyk, „Maur” czy jak jeszcze go można inaczej określić, pojawia się gdzieś w tle jako ktoś, z kim toczone są walki i kto wreszcie zostaje pokonany. Reprezentują go brudni i obdarci, kiepsko uzbrojeni jeńcy i zabici, pod koniec delegacje marokańskie u dowódcy zwycięskich wojsk negocjujące warunki pokoju, tym razem opisywane niemal z podziwem. Hardman odnosi się do nich z wyraźną obojętnością, a wojnę opisuje jak profesjonalny sprawozdawca wojenny nieulegający zbytnio (jeśli w ogóle) emocjom. Interesują go kolejne ruchy wojenne i liczby ofiar, a także, o czym 
już wspomniałem, warunki atmosferyczne - ale i one tylko chyba dlatego, że przez długi czas wstrzymywały działania na linii frontu, przez co korespondent bardzo się nudził. Maroko nie zostało w żaden sposób scharakteryzowane. Czytelnik właściwie nie do końca zdaje sobie sprawę, gdzie Hiszpanie i dołączające do nich oddziały brytyjskie, francuskie, austriackie czy niemieckie walczą. Chodzi tylko o wynik starć. Z relacji Fredericka Hardmana nikt kraju wroga ani jego mieszkańców nie pozna. „Innym” Hardman niewiele się interesuje, nie taki był cel jego wyprawy. Książka jest pozbawiona jakiegokolwiek materiału ilustracyjnego.

\section{Eduard Schlagintweit}

Eduard Schlagintweit (1831-866) („Schlagintweit, Eduard S.” 1890: 348; „Schlagintweit” 1911: 328) należał do znanej niemieckiej rodziny podróżników i badaczy m.in. Azji oraz Pacyfiku (bracia: Adolf, Eduard, Robert, Emil), ale był przede wszystkim żołnierzem. W wyprawie marokańskiej brał udział jako bawarski porucznik szóstego regimentu szwoleżerów. Choć był żołnierzem, nie brał bezpośredniego udziału w działaniach wojennych, a przez większą część wojny, aż do zajęcia Tetuanu przez Hiszpanów, pozostawał, podobnie jak większość z pozostałych 15 cudzoziemskich oficerów, w Kwaterze Głównej. „Tylko dwóm spośród nich - Austriakowi i Rosjaninowi - przypadło w udziale świętować chwałę tego dnia razem z Hiszpanami” - pisze we wstępie do swojego dzieła (Schlagintweit 1863: 18). Kontynuując po powrocie z Maroka swój niebezpieczny z natury zawód, zginął w bitwie pod Kissingen (Blätter für literarische Unterhaltung 1866: 591) w czasie kampanii meńskiej. Pozostawił po sobie poza relacją z wojny tetuańskiej rozprawę o sytuacji militarnej Anglii i Francji oraz dwie niewielkie publikacje związane z Marokiem: 1. Bericht über die spanische Armee in Marokko (1860) i Die militarischen Verhältnisse des Kaisertums Marokko zweiter Bericht (1860). Ta ostatnia książeczka została także przełożona na francuski i wydana w 1865 roku (État militaire de l'empire du Maroc) ${ }^{11}$.

Odległość czasowa dzieląca wydanie książki (nastąpiło to dwa lata po opisywanych wydarzeniach) sprawia być może, że relacja Schlagintweita ma odmienny od omówionych wyżej, specyficzny charakter, choć bardzo mocno przypomina relację Hardmana. Książka dzieli się na trzy części. Pierwsza została zatytułowana Politische und militärische Zustände Marokkos. I właśnie tu zawarto treści, których tak wielki brak odczuwałem w pracy Brytyjczyka. Tytuł tej części nie w pełni oddaje jej istotną zawartość. Faktycznie, częściowo mamy do czynienia z charakterystyką wojskowej organizacji Maroka. Trzeba przy tym przyznać, że jest to bardzo dobra charakterystyka, mogąca bez problemu służyć jako wiarygodne źródło historyczne z epoki, pożyteczne w badaniach dziejów kraju. Rozpoczynając swoją opowieść, Schlagintweit wskazuje na najważniejsze źródła, z jakich korzystał w tej części swej książki - są to opisy podróży i opracowania Alego Beya al-Abbasiego (Badía y Leblich 1814), Jacoba Gråberga von Hemsö (1833, 1834), Johna DrummondaHaya $(1844)^{12}$, Ferdinanda von Augustina (1838) czy Heinricha Kieperta, a zatem zarówno prace całkiem mu współczesne, jak i nieco starsze. Korzystał także z ważnych publikacji

\footnotetext{
11 Inna niemiecka relacja z tej wojny to Baeumen 1861.

12 Autor nie wymienia tytułu, ale najprawdopodobniej o tę właśnie książkę chodzi.
} 
hiszpańskich wydanych po wojnie. Przesuwając się jednak po kolei po wszystkich rozdziałach tej części, otrzymujemy ciekawy i kompetentny obraz Maroka w XIX wieku. Rozdział 1 to geograficzna charakterystyka kraju - topograficzna i klimatyczna. Na tym tle autor ukazuje szczegółowo „pole walki” (Details über den Kriegsschauplatz). Co ciekawe, Schlagintweit praktycznie pomija dzieje kraju. Jednak czytelnik dokładnie może sobie wyobrazić „wroga” i jego teren, na którym przyszło Hiszpanom i nielicznym innym Europejczykom zaangażowanym w guerra de África walczyć. Czytelnik dowiaduje się przede wszystkim o tym, kto mieszka w Maroku i jak zróżnicowani są jego mieszkańcy. Opisując poszczególne grupy etniczne, Niemiec krótko charakteryzuje ich wygląd oraz najważniejsze cechy charakteru Marokańczyków, dość stereotypowo podkreśla często ich „fałsz”, do którego powraca jeszcze pod koniec książki (Schlagintweit 1863: 328).

Autor szeroko opisuje Tetuan (ibid.: 25), podobnie jak inni podróżnicy (bez względu na cel podróży) zachwycając się białymi domami, palmami i pięknymi ogrodami miasta. Ciekawe, że w niewielkim stopniu koncentruje się na zniszczeniu miasta. Przyrodzie Maroka poświęca Niemiec całkiem spory opis (ibid.: 27-28). Wspomina także o islamie i tu zaskakuje oryginalna charakterystyka Ramadanu, który polega według niego przede wszystkim na „nicnierobieniu” (ibid.: 36). Schlagintweit zatrzymuje się także nad zwyczajami i obyczajami oraz wierzeniami tamtejszej ludności, zwracając szczególną uwagę na przesądy i właśnie wierzenia ludowe oraz sytuację kobiety (ibid.: 53-57). Poświęca również sporo miejsca strojowi mieszkańców Maroka, który dość dokładnie opisuje. Trudno stwierdzić, na ile wiadomości te pochodzą z obserwacji, na ile zaś są wynikiem wiedzy autora zdobytej z lektur. Schlagintweit nie zdradza również dokładnie, z jaką wiedzą do Maroka wyjechał - a zatem czy dostępne, wyżej wspomniane dzieła studiował wcześniej, czy też dopiero przygotowując swoją relację do druku. Na pewno jednak szczegóły dotyczące armii marokańskiej zbierał już po wojnie, przyjechawszy raz jeszcze do Afryki zaraz po zakończeniu działań militarnych (ibid.: X).

Druga część pracy jest poświęcona charakterystyce i sytuacji armii hiszpańskiej, dopiero zaś trzecia dotyczy samej wojny. Podobnie jak Hardman Schlagintweit opisuje wojnę z perspektywy obozu hiszpańskiego, poczynając od Ceuty. Forma relacji jest jednak odmienna. O ile Hardman przekazuje dokładnie datowane listy, zwracając się niejednokrotnie bezpośrednio do czytelnika, i zachowuje dość prywatny styl, o tyle tutaj mamy do czynienia po prostu ze sprawozdaniem, również opatrzonym dokładnymi datami. Wszystko jest jednak przekazywane bezosobowo, nie dowiadujemy się więc dokładnie ani kiedy Schlagintweit znalazł się w Maroku, ani kiedy stamtąd wyjechał. Autor, znajdując się, jako wysoko postawiony wojskowy, najprawdopodobniej $\mathrm{w}$ innej sytuacji niż brytyjski korespondent wojenny, przytacza sporo dokumentów, podaje także (tu analogicznie jak Hardman) wiele szczegółowych danych dotyczących przebiegu działań zbrojnych. Zwraca także oczywiście uwagę na specyficzną taktykę wojenną Marokańczyków, która, jak już wspomniałem, zadziwiała niemal wszystkich Europejczyków piszących o Maroku w tamtym czasie (Schlagintweit 1863: 221-223), przeciwstawiając ją typowej taktyce wojsk zachodnich. Co ciekawe, taktyka ta była opisywana i podobnie porównywana także przez ówczesnych kronikarzy marokańskich, np. przez cytowanego wyżej An-Nāșirīego, który z dużą estymą odnosił się do europejskiej sztuki walki (An-Nāșirī 2010: 333). Książka jednak jest napisana odmiennym językiem. Jej szczegółowość zdradza, że Schlagintweit musiał korzystać z dokładnych notatek oraz powojennych raportów wojskowych, o czym zresztą wspomi- 
na we wstępie (Schlagintweit 1863: 11). Praca może być zatem potraktowana nawet jako rodzaj monografii tejże wojny, uwzględnia bowiem liczne tabele i zestawienia dotyczące rozmaitych aspektów armii. Ciekawym uzupełnieniem okazuje się barwna mapa Maroka.

Tak więc w przypadku Der spanisch-marokkanische Krieg, inaczej niż u Hardmana, czytelnik może do pewnego stopnia „poznać wroga”. Nie jest to obraz wyróżniający się na tle XIX-wiecznych opisów Maroka - niemieckich, austriackich, francuskich czy hiszpańskich. Opisując działania wojenne, rzadko odnosi się do Marokańczyków jako takich. Relacja pozostaje sucha i rzeczowa, brak w niej nawet tego typu „smaczków”, jak opisy stanu jeńców marokańskich czy też poległych żołnierzy sultana, których kilkakrotnie opisuje Hardman, nie mówiąc już o egzaltowanych emocjach de Alarcóna. Jednakże i on zwraca często uwagę na stan pogody, która w trakcie tej wojny rzeczywiście Europejczykom nie sprzyjała. Jedyny żywszy fragment stanowi opis Tetuanu po zdobyciu miasta przez Hiszpanów (ibid.: 328). A zatem i ta relacja nie pozwala sama przez się poznać wroga czytelnikowi jego książki, choć pozostaje ona bezcennym źródłem dla badaczy historii XIX-wiecznego Maroka. Wróg jest bezosobowy, ale - co ciekawe, „nasi”, czyli europejscy żołnierze też pozostają bezosobowi. Armia walczy z armią, żołnierze z żołnierzami, nie ludzie z ludźmi. Toteż dla poznania recepcji „innego” relacja Schlagintweita pozostaje źródłem bardzo skromnym.

\section{Zakończenie}

Choć wszyscy trzej autorzy znajdowali się w tych samych miejscach w tym samym czasie, choć opisują te same fakty historyczne w dokładnie taki sam sposób, żaden z nich nie wspomina drugiego, co wydaje się zadziwiające. O ile można to do pewnego stopnia zrozumieć w przypadku de Alarcóna, który z pewnością miał najwięcej swobody ze wszystkich trzech omówionych tu autorów, to zaskakuje taka sytuacja w przypadku pozostających stale w obozach Schlagintweita i Hardmana. Ale fakt ten tylko wzmiankuję, nie mając nadziei na jego wyjaśnienie.

Jak wspomniałem na początku, celem tego opracowania było zbadanie, jak ziemia wroga i wróg zostali zaprezentowani w europejskich relacjach o wojnie hiszpańsko-marokańskiej lat 1859-1860; jak podróż do nie tylko obcego, ale obcego naznaczonego jednoznacznie jako wróg ukształtowała jego obraz w świadomości autorów relacji oraz, co za tym idzie, u odbiorców ich książek. Wybór tych, a nie innych postaci był podyktowany ich rozmaitym pochodzeniem, a zatem i innymi odbiorcami, a także odmiennym charakterem udziału w działaniach wojennych.

Wnioski z analizy okazują się niejednoznaczne. Najciekawszy obraz Maroka i Marokańczyków przekazuje bez wątpienia hiszpański korespondent wojenny Pedro Antonio de Alarcón. Jego relacja ma najgłębszy charakter - można powiedzieć, że Hiszpan wojnę przeżywał najbardziej osobiście. I nic w tym dziwnego - była to wojna prowadzona przez jego kraj. Ale też należało spodziewać się w związku z tym, że „wróg” (tak bardzo często określają Marokańczyków wszyscy trzej autorzy: „enemigo”, „enemy”, „der Feind”) będzie tu opisany najbardziej odstręczająco. Okazało się natomiast, że właśnie de Alarcón przedstawia Maroko i Marokańczyków w sposób najciekawszy, najbardziej malowniczy i niemal przyjacielski. Dla Brytyjczyka Hardmana Maroko to przede wszystkim kraj brud- 
ny, zacofany i despotycznie rządzony, zaś Marokańczycy są biedni i brudni (wątek brudu $\mathrm{u}$ tego autora pojawia się wyjątkowo często). Jednak opinii tych należy dobrze w książce szukać, choć przecież w pierwotnej wersji była drukowana jako rodzaj raportów czy też reportaży z wojny i jest napisana raczej lekkim, dostępnym stylem. Z kolei dla niemieckiego autora, pedantycznego żołnierza, wróg jako człowiek praktycznie nie istnieje. Istnieją tylko oddziały, obozy i armie. Maroko swojemu czytelnikowi przedstawia na początku książki, która w całości jest niemalże pozbawiona osobistych odniesień i ocen.

Wroga i jego ziemie może zatem poznać czytelnik każdorazowo tylko na tyle, na ile autor uzna to za stosowne w kontekście maniery swojego przekazu. Orientalizm XIX-wieczny $\mathrm{w}$ bardzo rozmaitym stopniu wpłynął na obrazowanie tych samych wydarzeń, które raz rozgrywają się w malowniczym krajobrazie północnego Maroka, a raz po prostu na linii frontu...

\section{Bibliografia}

Alarcón, Pedro Antonio de 1859. Diario de un testigo de la guerra de África. Madrid: Gaspar y Roig. — 1861. Diario de un testigo de la guerra de África. Wyd. 2. [Mexico]: Imprenta de Luiz Inclan.

A[lger],J. G. 1890. Hardman, Frederick. W: L. Stephen, S. Lee (red.). Dictionary of National Biography. T. XXIV. London: Macmillan and Co., New York, Smith \& Elder and Co.

Allan, Stuart, Zeliger Barbie (red.) 2004. Reporting War Journalism. Journalism in Wartime. London: Routlege.

Atlas histórico y topográfico de la guerra de África sostenida por la nacion española contra el imperio marroqui en 1859 y 1860.1860 . Madrid: b.w.

Augustin, Ferdinand von 1838. Erinnerungen aus Marokko, gesammelt auf einer Reise im Jahre 1830. Wien: Schaumburg.

Baczyńska, Beata 2014. Historia literatury hiszpańskiej. Warszawa: PWN.

Badía y Leblich, Domingo 1814. Voyages d'Ali Bey el Abbassi en Afrique et en Asie pendant les années 1803, 1804, 1805, 1806 et 1807. Paris: L’Imprimerie de P. Didot l'Aîné.

Baeumen, August von 1861. Nach Marokko. Reise- und Kriegsmemoiren. Berlin: Verlag von Julius Springer.

Balaguer, Victor 1860a. Jornadas de gloria ó los Españoles en África. Madrid: Libreria Española.

- 1860b. Reseña de los festejos celebrados en Barcelona en los primeros dias de mayo de 1860 con motivo del regreso de los voluntarios de Cataluña y tropas del ejército de África. Madrid-Barcelona.

Blätter für literarische Unterhaltung 1866. T. II, 37 (13.09).

Cayal Valero, Arturo 2012. „La participación de los tercios vascongados en la guerra de África (1859-1860)". Revista de Historia Militar 112: 125-196.

Chandler, Richard E., Kessel Schwartz 1991. A new History of Spanish literature. Baton Rouge: Louisiana State University Press.

„Contemporary Literature. III. Magazine-Writers” 1879. Blackwood's Edinburgh Magazine CXXV, DCCLX (February): 235-236.

Crespo Giménez, Francisco 2017. El Costumbrismo exótico de Mariano Fortuny, http:/ /www.cervantesvirtual.com/bib/romanticismo/actas_pdf/romanticismo_6/crespo.pdf [10.02.2017].

Drummond-Hay, John 1844. Western Barbary. Its Wild Tribes and Savage Animals. London: John Murray.

Gies, David T. (red.) 2008. The Cambridge History of Spanish Literature. Cambridge: Cambridge University Press. 
Gråberg von Hemsö, Jacob 1833. Das Sultanat Mogh'rib-ul-Aksà, oder, Kaiserreich Marokko. In Bezug auf Landes-, Volks- und Staats-kunde. Stuttgart-Tübingen: Gotta’sche Buchhandlung.

- 1834. Specchio geografico, e statistico dell'impero di Marocco. Genova: Tipografia Pellas.

Hardman, Frederick 1846. Peninsular scenes and sketches. London: William Blackwood and Sons.

- 1847. The Student of Salamanca. London: William Blackwood and Sons.

- 1860. The Spanish Campaign in Morocco. Edinburgh-London: William Blackwood and Sons.

Heymel, Charlotte 2007. Touristen an der Front. Das Kriegserlebnis 1914-1918 als Reiseerfahrung in zeitgenössischen Reiseberichten. Berlin: LIT Verlag.

Kiepert, Heinrich. „Bemerkungen zu der Karte von Marokko”, Zeitschrift für allgemeine Erdkunde.

Knightley, Philip 2004. The First Causality. The War Correspondent as Hero and Mythmaker from the Crimea to Iraq. Baltimore, MD: John Hopkins University Press.

Korte, Barbara, Horst Tonn 2007. Kriegskorrespondenten: Deutungsinstanzen in der Mediengesellschaft. Wiesbaden: VS Verlag für Sozielwissenschaften.

Królikowski, Bohdan (red.) 2003. Diariusz wyprawy wiedeńskiej króla Jana III. Lublin: Towarzystwo Naukowe KUL.

Montañés, José Ángel 2013. „Tetuán: 'making of' de una batalla”, El País 18 IV, http://ccaa.elpais. com/ccaa/2013/04/17/catalunya/1366205667_689483.html [20.02.2017].

Moro, C., Bouret A. (red.) 1859-1860. Episodios de la Guerra de África. Madrid.

An-Nāṣirī, Aḥmad Ibn Hāāid 2010. Kitāb al-istiqșā li-ah̆bār duwal Al-Māgrib al-Aqșā. T. III. Bayrūt: Dār al-Kutub al-'Ilmiyya.

Pérez, Jesús M. 2008. La Guerra de África en Pedro Antonio de Alarcón. W: Carmen A. Segura, José A. Carballar Jurado, Antonio Castro Díaz (red.). Anuario de los cursos 2000-2008. Sevilla: Asociación Andaluza de Profesores de Español Elio Antonio De Nebrija.

R. R. de M. 1860. Crónica de la guerra de Africa. Madrid: Juan José Martínez.

Ryan, Chris 2007. Battlefield Tourism. History, Place and Interpretation. Amsterdam et al.: Elsevier.

Schlagintweit, Eduard 1863. Der spanisch-marokkanische Krieg in den Jahren 1859 und 1860. Leipzig: Brockhaus.

„Schlagintweit, Eduard S.” 1890. W: Allgemeine Deutsche Biographie. Bd. 31. Leipzig: Duncker\&Humbolt.

„Schlagintweit” 1911. W: Encyclopaedia Britannica. Wyd. 11. T. XXIV. Cambridge: Cambridge University Press.

Serrallonga Urquidi, Joan 1998. „La guerra de África (1859-1860). Una revisión”, Ayer 29: 139-159.

„Tiṭwān fī kitāb „Yawmiyyāt šāhid 'an hạarb Ifrikkiyyā”” 2017. D'awat al-Haqq, http://www.habous. gov.ma/daouat-alhaq/ [20.02.2017].

Tuñón de Lara, Manuel, Julio Valdeón Baruque, Antonio Domínguez Ortiz 2012. Historia Hiszpanii. Tłum. Szymon Jędrusiak. Kraków: Universitas.

Velasco, Rocío 2013. „Objetivos y limitaciones de la política exterior española en Marruecos: la batalla de Tetuán (1859-1860". Revista Historia Autónoma 2: 93-106.

Wölki, Kerstin 2007. Die Wahrnehmung Frankreichs durch deutsche Soldaten im Zweiten Weltkrieg. Freiburg i. Br.: Albert-Ludwig-Universität. 